\section{From Brain Drain to Brain Circulation}

\section{M.A. Kana; MBBS, MPH}

\author{
Department of Community Health, Jos University Teaching \\ Hospital \\ musakana77@yahoo.com
}

"The emigration of African professionals to the West is one of the greatest obstacles to Africa's development." - United Nations Economic Commission for Africa (ECA)

\section{Introduction}

A brain drain or human capital flight is an emigration of trained and talented individuals ("human capital") to other nations or jurisdictions, due to conflicts, lack of opportunity, health hazards where they are living or other reasons. Spokesmen for the Royal Society of London coined the expression "brain drain" to describe the outflow of scientists and technologists to Canada and the United States in the early 1950s. Its counterpart is brain gain in the areas to which talent migrates. Brain drain can occur either when individuals who study abroad and complete their education do not return to their home country, or when individuals educated in their home country emigrate for higher wages or better opportunities. This phenomenon is perhaps most problematic for developing nations, where it is widespread. In these countries, higher education and professional certification are often viewed as the surest path to escape from a troubled economy or difficult political situation. Brain drain can be described as "soft brain drain" which is the non-availability of research results from a country where the study was carried out. This could be due to a publication of the findings in an international journal to which health practitioners from the study country have little access. This is different from the physical movement of persons from the developing countries to northern nations "hard brain drain2".

In the past, the migration of skilled health professionals from poorer to richer countries was essentially a passive process. Movement was driven mainly by the political, economic, social, and professional circumstances of the individual migrant. In recent years, however, demand for health workers in many countries in the Organization for Economic Cooperation and Development have been greatly increased by changes in population dynamics. In response, some of these countries are relying increasingly on imported labour, with potentially damaging consequences for the healthcare systems in many developing countries, especially Africa. Indiscriminate poaching of health professionals is also likely to damage receiving countries in the long term. If we were to consider the minimum standard set by the World Health Organization (WHO) to ensure basic healthcare services is 20 physicians per 100,000 people. While Western countries boast an average of 222, 38 countries in sub-Saharan Africa fall short of the minimum standard and 13 of these have 5 or fewer.

There is increased attention and widespread controversy surrounding the international movement of health professionals, one strand of debate considers the health workforce shortages affecting some of the world's poorest countries, especially in sub-saharan Africa, which is most affected by the HIV/AIDS pandemic. The second strand of debate focuses on the destination countries of international migrants and explores the factors prompting the increased employment of overseas health professionals and the consequences for health systems. Underlying these developments is recognition that the mobility of health professionals is an integral component of the globalization process whose consequences continue to be fiercely contested,. And this is vividly expressed in the words of the German interior minister Otto Schily: "There's competition among the industrialized countries for the best minds. That's why we have to direct our immigration law more strongly towards our own economic interests."

Indeed we now live in a global village with improvements in telecommunication, transportation and free trade, leading to a historically unprecedented ease in international movement of people, goods and services. But our global village is characterized by lots of imbalances and imperfections; there is over-concentration of wealth and better opportunities in the richer parts of the world and thus creating a state of political instability, economic frustration and social unrest in the disadvantaged parts of the global village. Though, internal destabilizing factors are present in such poor countries. Evidently a clash of progress, ethics and morals is unfolding. Do we humans degenerate to an animal-like "strong takes" it all, in a predator (richer countries) and prey (poorer countries) situation? The moral regard to this issue cannot be under-recognized.

Health crisis is facing sub-Saharan Africa. The population has increased markedly. In recent decades, communicable diseases and 'new' non-communicable disease epidemics have intensified. HIV/AIDS is perhaps the biggest health challenge. In addition, perennial problems stem from the economic difficulties of countries in sub-saharan Africa, which affect health systems through low funding and a deterioration of the infrastructure of health systems. Unfortunately, African health systems are in the grip of a "brain drain": About 20,000 health professionals are estimated to emigrate from Africa annually. In Zimbabwe, three-quarters of all doctors emigrate within a few years of completing medical school. In Kenya and Ghana, the brain drain of medical professionals is threatening the very existence of the countries' health services. Kenya loses on average 20 medical doctors each month. Ghana lost $60 \%$ of its medical doctors in the 1980s and 600-700 Ghanaian physicians are currently practicing in the USA alone, a figure that represents roughly $50 \%$ of the total population of doctors in Ghana. The 1993 UNDP Human Development Report indicated that more than 21,000 Nigerian doctors were practicing in the United States alone while Nigeria suffers from a shortage of doctors. In addition to the number of Nigerian doctors in Saudi Arabia and the Gulf States, Europe, Australia and those in other African countries, the figure would be close to 30,000. The situation in Ethiopia is appalling, were one third of the medical doctors have already left the country. And another report states that there are more Ethiopian-trained doctors practicing in the city of Chicago alone than in Ethiopia. In Zambia, the public sector only retained 50 out of 600 doctors trained in the country's medical school from 1978-1999. The flight of health professionals is not limited to doctors and affects nurses, pharmacists and social services personnel as well5.

Although the developed countries of the North are giving aid with one hand, they are robbing African countries with 
the other by siphoning off their most precious resourcetrained doctors and nurses. The Commonwealth's developing countries are particularly hard hit because their health professionals speak English and are therefore a valuable commodity to plug manpower gaps in the United States, Canada, the United Kingdom, New Zealand, and Australia. The United States employs half of all English speaking doctors in the world. And it wants more. By deadly coincidence, the US wants to employ one million more healthcare workers in the next 15 yearsexactly the extra number needed for sub-saharan Africa to fulfill the millennium development goals. The US system regards healthcare professionals as a commodity to be purchased in the market and is making little provision currently to increase the number of doctors and nurses it trains at home

\section{Causes and consequences of brain drain}

Emigration results from a combination of push factors (in source countries) and pull factors (in recipient countries). The reasons for scientific researchers failing to return to their home countries after training abroad include: lack of research funding; poor research facilities; limited career structures; poor intellectual stimulation; threats of violence; lack of good education for children in home country,; and lack of the evidence-based decision-making culture, leading to lack of recognition of potential contribution of researchers to national health development.

The key push factors driving out health workers include: weak health systems; insecurity including violence at the workplace; poor living conditions; low remunerations; lack of professional development opportunities (e.g. continuing education or training); lack of clear career development paths; and risk of HIV infection due to lack of appropriate protective gear when handling specimens, blood and blood products; nepotism in recruitment and promotion; political unrest/civil wars; widespread poverty; poor governance; and case overload (leading to burnt out syndrome in health workers).

Some of the factors that pull professionals to developed countries may include: availability of information, easy access to communication and technology, making it easy to find jobs or complete visa applications and process; aggressive targeted recruitment to fill vacancies in richer countries (United Kingdom has a good number of medical graduates who leave the medical profession out of despair); availability of employment opportunities; better remunerations and working conditions; secure and conducive living conditions and opportunities for intellectual growth (e.g. refresher courses, access to Internet and modern library facilities).

Surprisingly, some middle-income countries like the Philippines train health workers for international export. The World Health Report 2006 states that: "The government of the Philippines has encouraged temporary migration by its professionals in recent years and taken measures to turn remittances into an effective tool for national development by encouraging migrants to send remittances via official channels. In 2004, the Central Bank of the Philippines reported total remittances of US\$8.5 billion, representing $10 \%$ of the country's gross domestic product (GDP)" (p.101).

The mass emigration of skilled health professionals is not a neutral event. At present the costs and benefits are unevenly distributed,. The host countries benefit from short term relief of labour shortages, increase in available human capital, stimulation of capacity for innovation, savings in educational costs, and increased global competitiveness. The potential benefits to the origin countries include financial gains through remittances, skills transfer, and possible investment if workers return. However, all these are trivial compared with the losses, which include loss of public educational investment, loss of intellectual capital, reduced range of available services, chronic understaffing of health facilities, and poor healthcare services, , In extreme cases, a widening of the population health gap may result in reduced productivity, loss of national economic investment, and potential damage to economic development 25, . Affected developing countries face difficult choices. They can neither control the outflow of skill nor ignore its consequences on the larger community. The right of the individual health worker to emigrate has to be balanced against the consequences of such migration on the welfare of the larger society. This problem has rekindled an old debate between those who view skilled migration as the rational expression of the right of individuals to maximize their utility and those who view it as concealed exploitation of poorer countries by the richer countries 14 , .

\section{Initiatives to mitigate brain drain: converting drain to circulation}

Since the limited human resources for health are the head, heart and hands of the national and district health systems, the continued plunder of investments embodied in human resources contributes to: 1) the growing double burden of communicable and non-communicable diseases (by weakening health promotion and primary and secondary prevention); 2) further underdevelopment of the developing countries; and 3) keeping a large proportion of the population in the vicious circle of poverty and ill-health. Economic arguments notwithstanding, ultimately the price of emigration of human resources for health in the developing world is considerable. This unacceptable situation should be urgently reversed through joint action by both developing and developed countries.

Currently there are several national and international initiatives with the goal of mitigating the problem of brain drain. A joint communiqué issued by the Council of the Commonwealth Medical Association, representing 700,000 doctors from 35 Commonwealth countries, and the membership of the Ghana Medical Association called for a renewed effort by the UK, the OECD and the G8 countries to find innovative, sustainable solutions to the African 'brain drain' in the health sector. But the initiative of the G8 countries will fail spectacularly if the richest nations of the world do not allow the poorest to maintain the bare essentials of healthcare provision13.

Successful international action will require a global framework for the management of skills migration. It is critical to engage the active participation and cooperation of all the major players: major developed countries, major developing countries, multilateral agencies, and representatives of the health professions4.

The Diaspora option (or, "virtual participation") which encourages highly skilled expatriates to contribute their experience to the development of their country without necessarily physically relocating emerged in the early 1990 s 
as a more realistic strategy to alleviate the consequences of brain drain should be encouraged.(brain drain Africa: facts and figures)

Clearly, the shortage of health professionals has no simple solution4. The problem is global and therefore requires a global solution. But consideration is to be given to the two sides of the problems in terms of the push and pull factors. And a departure from brain drain to achieve a sort of brain exchange (circulation) will require attaining a balance between the two factors. This will translate into the improvement of governance and the socio-economic situation of developing countries on one part, and on the other part the legitimate labour needs of the developed countries should be met without damaging the health systems of the developing countries 4 .

\section{Conclusion}

Medicine has a strong tradition of international collaboration, with doctors moving around the globe to gain further training and different clinical experience. Indeed, we like to think that international exchange and diversity enrich us all. This is a romantic delusion. The North gains, but developing countries lose out by losing their doctors permanently13. Any number of incentives have been tried to persuade doctors to remain in or return to their countries of originenhanced salaries, better pensions, cars, and housing allowances. But, as long as the rich countries have plenty of vacancies, the flow of healthcare professionals from South to North will continue.

"[By] failing to offer greener pastures for its own intelligentsia, [Africa] is committing suicide." - Professor Edward Ofori-Sarpong, Pro-Vice Chancellor, University of Ghana at Legon.

\section{References}

1. B r a i d r a i n. A v a 1 a b l e f r o m : http://www.wikipedia.org/wiki/Brain_drain. (Accessed 8th September, 2007).

2. Muula AS. Is There any Solution to the Brain Drain of Health Professionals and Knowledge from Africa? Croat Med J2005; 46(1): 21-29.

3. Ahmad OB. Managing medical migration from poor countries. BMJ 2005; 331: 43-45.

4. Brain drain in Africa: facts and figures. Available from: http://web.ncf.ca/cp 129/factsandfigures.pdf (Accessed 8th September, 2007).

5. Stiglitz J. Why we are paying the Price for the Greediest Decade in History. London: Penguin; 2004.

6. Wolf M. Why Globalization Works. New Haven CT: Yale University Press; 2004

7. Schily OV. Germany: Schily proposal. Migration News 2001; 8 (9). Available from:

http://migration.ucdavis.edu/mn/more.php (Accessed 8th September, 2007).

8. Dovlo D. The Brain Drain in Africa: An Emerging Challenge to Health Professionals' Education. JHE A/RESA 2005; 2 (3): 118.

9. Raufu A. Nigerian health authorities worry over exodus of doctors and nurses. BMJ 2002; 325:65.

10. Plugging the brain drain. Available from: http://www.bbc.co.uk/home/bbcnews/world/africa/plugging thebraindrain (Accessed 8th September, 2007).

11. Johnson J. Stopping Africa's medical brain drain. BMJ 2005; 331:23.
12. Developing countries take a creative approach to research and development. Bull World Health Organ 2005; 83(1): 180.

13. Pang T, Lansang MA, Haines A. Brain drain and health professionals. BMJ 2002; 324:499-500.

14. Kupfer L, Hofman K, Jarawan R, McDermott J, Bridbord K. Strategies to discourage brain drain. Bull World Health Organ 2004; 82(8):616-623.

15. Stilwell B, Zurn P, Connell J, Awases M. The migration of health workers: an overview. Geneva: World Health Organization; 2005.

16. Thein HO. Brain drain disseminates skill and advances science. BMJ 2002; 325: 219.

17. Stilwell B, Diallo K, Zurn P, Vujicic M, Adams O, Poz MD. Migration of healthcare workers from developing countries: strategic approaches to its management. Bull World Health Organ 2004, 82 (8): 595-600.

18. World Health Organization. The World Health Report 2006: Working together for health. Geneva: WHO; 2006.

19. Organization for Economic Co-operation and Development. International mobility of the highly skilled. Paris, OECD 2002.

20. International Labour Organization. Social dialogue in the health services: institutions, capacity and effectiveness. Geneva: ILO; 2002 . Available from : www.ilo.org/public/english/dialogue/sector/techmeet/jms02/ jmhs-r.pdf (Accessed 8th September, 2007).

21. The competition for global talent. Financial Express 2005 Feb 8.

22. Regets MC. Research and policy issues in high-skilled international migration: a perspective with data from the United States. Arlington VG: National Science Foundation; 2001.

23. Buchan J, Parkin T, Sochalski J. International nurse mobility: trends and policy implications. Geneva: World Health Organization; 2003. Available from:

www.icn.ch/interbnationalnursemobility.pdf (Accessed 8th September, 2007).

24. Adams O, Kinnon C. A public health perspective. International trade in health services: a developmental perspective. Geneva: World Health Organization; 1998.

25. Mejia A, Pizurki H, Royston E. Physician and nurse migration: analysis and policy implications. Geneva: World Health Organization; 1979.

26. Organization for Economic Co-operation and Development. Trends in international migration. Paris: $\quad$ OECD; 1997.

27. Carrington WJ, Detragiache E. How extensive is the brain drain? Finance Dev 1999; 36:46-9.

28. Couper ID, Worley PS. The ethics of international recruitment. Rural and Remote Health 2002; 2:196. Available from: http://rrh.deakin.edu.au/articles/subviewnew.asp (Accessed 8th September, 2007)

29. Mercer H, Poz MD, Adams O, Stiwell B, Buchan J, Dreesch N, Zurn P, Beaglehole R. Human resources for health: developing policy options for change. In: Ferrinho P, Poz MD, editors. Towards a global health workforce strategy. Antwerp: ITG Press; 2003. p.451-482.

30. Kirigia JM, Gbary AR, Muthuri LK, Seddoh JNA. The cost of health professionals' brain drain in Kenya. BMC Health Services Research 2006; 6:89.

31. Commonwealth Medical Association, Ghana Medical Association. Communiqué of the Joint Commonwealth Medical Association 20th Triennial Consultation/Conference and the 46th Annual General Conference of the Ghana Medical Association. Elmina and Cape Coast, Ghana; November 7-14, 2004. 